\title{
VALIDASI METODE AANI DALAM HUBUNGANNYA DENGAN FASILITAS IRADIASI SISTEM RABBIT RSG-GAS
}

\author{
ELISABETH RATNAWATI, TH. RINA M \\ Pusat Reaktor Serba Guna (PRSG)-BATAN \\ Kawasan Puspitek Serpong Tangerang 15310 \\ Banten Telp. 021-7560908
}

\begin{abstract}
Abstrak
VALIDASI METODE AANI DALAM HUBUNGANNYA DENGAN FASILITAS IRADIASI SYSTEM RABBIT RSG-GAS. Telah dilakukan validasi metode AANI dengan menggunakan beberapa bahan acuan standar bersertifikat. Validasi metode ini mengacu pada ketentuan yang dikehendaki dalam SNI 19-17025-2005: 5.4.5.1. Berdasarkan hasil validasi metode yang dilakukan melalui pengujian akurasi dan presisi metode, akan dicoba dilihat kaitannya dengan fasilitas iradiasi yang digunakan untuk mengaktifkan sampel. Aktivasi dilakukan pada rabbit system (RS1, RS2, RS3, dan RS4). Hasil validasi menunjukkan bahwa aktivasi sampel yang dilakukan pada fasilitas RS1, RS2, RS3 cukup baik, sedangkan RS4 memberikan hasil pengujian dengan tingkat presisi dan akurasi yang tidak memenuhi syarat (ditolak). Perbedaan hasil yang cukup signifikan ini tidak dipengaruhi oleh posisi fasilitas iradiasi di reaktor, karena dari hasil pengukuran menunjukan bahwa fluks neutron pada ke-empat posisi tersebut memiliki kisaran yang hampir sama yaitu $1013 \mathrm{n} \mathrm{cm}^{-2} \mathrm{~s}^{-1}$.
\end{abstract}

Kata kunci : validasi, AANI, Fasilitas iradiasi, sistem rabbit

\begin{abstract}
THE VALIDATION OF INAA METHOD IN THE RELATION WITH RABBIT SYSTEM OF RSG-GAS IRRADIATION FACILITY. The validation of INAA method has been done by standard reference material. This validation of INAA method is implemented based on the criteria of SNI 19-17025-2005: 5.4.5.1. Based on the result of this work will be shown the relation between performance of irradiation facility used by sample activated with the result of accuration and precision test. The samples ware activated in the rabbit system (RS1, RS2, RS3, and RS4). The result of validation showed that the sample was activated in the RS1, RS2, and RS3 gave good result, but RS4 is not so good. The significant deference result is not been influenced by position of irradiation facility in the reactor, because of the neutron flux measurement gave same result for the all position (RS1, RS2, RS3, and RS4) is $\approx 1013 \mathrm{ncm}^{-2} \mathrm{~s}^{-1}$.
\end{abstract}

Key words: validation, INAA, irradiation facility, rabbit system 


\section{PENDAHULUAN}

Metode analisis aktivasi netron (AAN) adalah metode pengujian tidak baku. Untuk memperoleh pengakuan sebagai metode analisis yang digunakan di laboratorium pengujian terakreditasi, maka harus divalidasi terlebih dahulu. Melalui kegiatan validasi ini akan diuji kemampuan personil dan fasilitas yang digunakan. Pengujian presisi perlu dilakukan untuk mendapatkan gambaran besar kesalahan acak dalam suatu analisis. Sedangkan pengujian akurasi perlu dilakukan untuk mendapat gambaran ketepatan penyimpangan data hasil analisis terhadap harga sesungguhnya. Kegiatan validasi ini merupakan kelanjutan dari kegiatan sebelumnya, dimana telah dilakukan validasi untuk jenis bahan acuan standar yang berbeda.

Reaktor Serba Guna GA Siwabessy dilengkapi dengan fasilitas iradiasi 5 sistem rabbit, yaitu 4 sistem rabbit dengan kecepatan normal (sistem hidrolik) dan 1 sistem rabbit dengan kecepatan tinggi (sistem pneumatik). Fasilitas ini berguna untuk iradiasi bahan di dalam reaktor. Selama reaktor beroperasi, sistem rabbit memungkinkan pemindahan sampel yang akan diiradiasi ke dalam daerah inti/core reaktor untuk diiradiasi dan pengeluaran sampel yang telah diiradiasi untuk dievaluasi.

Pada analisis/pengujian bahan dengan akitivasi neutron yang mana aktivasi ini dilakukan di fasilitas sistem rabbit reaktor, maka kinerja sistem ini sangat menentukan. Untuk mendapatkan hasil pengujian yang akurat dan memiliki reprodusibilitas tinggi, maka akan coba dilihat hubungan antara kemampuan fasilitas iradiasi sistem rabbit dengan hasil pengujian yang diperoleh. Hal ini berkaitan dengan nilai fluks neutron yang mungkin bervariasi pada setiap lokasi di reaktor. Karena itu pada penelitian ini akan dilakukan validasi metode AANI dengan Bahan acuan standar yang dikeluarkan oleh NIST, sebagai dasar untuk mengetahui kinerja fasilitas iradiasi yang ada di RSG-GAS. Sistem rabbit hidrolik yang saat ini biasa digunakan pada proses iradiasi bahan, yaitu Rabbit System 1 (RS1), RS2, RS3 dan RS4. Sebelumnya sistem rabbit yang sering digunakan adalah RS1 dan RS2. Dari hasil penelitian ini diharapkan bahwa proses aktivasi dengan menggunakan ke empat posisi sistem rabbit hidrolik memberikan hasil yang dapat dipercaya. Evaluasi hasil akan dilihat hubungan antara hasil validasi metode (uji presisi dan akurasi) tiap unsur terhadap lokasi yaitu fasilitas iradiasi system rabbit dimana aktivasi sampel dilakukan.

\section{DASAR TEORI}

\section{Fasilitas Iradiasi}

Fasilitas-fasilitas iradiasi yang ada di RSG-GAS ${ }^{[1]}$ ditinjau dari posisinya dapat dibagi menjadi tiga yaitu: fasilitas yang terletak di teras reaktor, fasilitas yang terletak di berilium dan fasilitas yang terletak di samping teras reaktor. Fasilitas 
yang terletak di teras reaktor digunakan untuk produksi radioisotop, dan penelitian elemen bakar reaktor daya yang memerlukan fluks neutron tinggi. Fasilitas iradiasi yang terletak diberilium digunakan untuk produksi radioisotop dan penelitian aktivasi neutron. Fasilitas yang terletak di samping teras reaktor digunakan untuk silikon doping, neutron radiografi dan penyediaan tabung berkas neutron.

\section{Rabbit System (RS)}

RS adalah fasilitas iradiasi untuk melakukan penelitian aktivasi neutron dan produksi radioisotop. Ada dua jenis sistem rabbit yaitu hidrolik dan pnumatik. Media pengangkut kapsul iradiasi pada sistem rabbit hidrolik adalah air sedangkan media pengangkut pada sistem rabbit pneumatik adalah gas nitrogen. Di samping sebagai media pengangkut, air dan gas ini berfungsi sebagai pendingin kapsul selama iradiasi berlangsung. Sistem rabbit pada dasarnya terdiri atas:

1. stasiun iradiasi

2. tabung/pipa

3. stasiun pengiriman dan penerimaan,

4. sistem proses

5. elektroteknikal, instrumentasi dan sistem control

\section{Neutron dan Reaksi Nuklir}

Ada beberapa jenis sumber neutron (reaktor, akselator dan radioisotop pemancar neutron), tetapi yang paling baik digunakan untuk keperluan analisis aktivasi neutron adalah reaktor nuklir, karena memiliki fluks neutron yang tinggi dari hasil reaksi fisi ${ }^{235} \mathrm{U}$. Neutron yang dihasilkan dari reaksi fisi memiliki kisaran energi hingga $15 \mathrm{MeV}$ dan energi rata-rata sekitar $2 \mathrm{MeV}$. Melalui tumbukan elastik dengan inti moderator, dengan cepat neutron hasil fisi tertermalisasi menjadi neutron thermal, epitermal dan neutron cepat. Neutron thermal memiliki energi rendah di bawah $0,5 \mathrm{eV}$. Pengukuran fluks neutron termal pada umumnya dilakukan dengan fluks monitor cobalt dengan reaksi ${ }^{59} \mathrm{C} 0(\mathrm{n}, \gamma){ }^{60} \mathrm{Co}$, yang memiliki tampang lintang 37,1 barn $\left(1\right.$ barn $=10^{-24} \mathrm{~cm}^{2}$ 
Tabel 1. Rancangan Dasar Sistem Rabbit ${ }^{[1]}$

\begin{tabular}{|c|c|c|}
\hline Deskripsi & Sistem rabbit hidrolik & Sistem rabbit pneumatik \\
\hline Jumlah & 4 & 1 \\
\hline Ukuran pipa transfer & Diameter dalam $36 \mathrm{~mm}$ & Diameter dalam $20 \mathrm{~mm}$ \\
\hline $\begin{array}{l}\text { Media pengangkut } \\
\text { dan pendingin }\end{array}$ & Air & Gas nitrogen \\
\hline Material pipa transfer & $\begin{array}{l}\text { Dalam kolam } \mathrm{AlMg}_{3} \text {, luar kolam stainless } \\
\text { steel }\end{array}$ & $\begin{array}{l}\text { Dalam kolam } \mathrm{AlMg}_{3} \text {, luar } \\
\text { kolam stainless steel }\end{array}$ \\
\hline Tekanan operasi & Tekanan sekeliling & 1,5 bar \\
\hline Kecepatan transfer & $0,6 \mathrm{~m} / \mathrm{dt}$ & $10 \mathrm{~m} / \mathrm{dt}$ \\
\hline Material rabbit & Plastik, aluminium & Plastic \\
\hline $\begin{array}{l}\text { Lama iradiasi } \\
\text { minimum }\end{array}$ & $0,2 \mathrm{dt}$ & $0,2 \mathrm{dt}$ \\
\hline $\begin{array}{l}\text { Kecepatan pendingin } \\
\text { disekeliling kapsul }\end{array}$ & Minimum $0,6 \mathrm{~m} / \mathrm{dt}$ & Minimum $35 \mathrm{~m} / \mathrm{dt}$ \\
\hline Bahan diiradiasi & $\begin{array}{c}\text { - kimia anorganik (KCl, KBr, dll) } \\
\text { - kimia organik (glikogen,polystyrene,dll) } \\
\text { - Eksperimen physic (Gd+Eu, dll) } \\
\text { - Biofisik (tiroid, Iodin, dll) } \\
\text { - Kelautan (Mn, kerang, dll) } \\
\text { - Teknologi semikonduktor (Ge, Si, dll) } \\
\text { - material fisik (Co, Ni, Cd, dll) } \\
\text { - Makanan }\end{array}$ & $\begin{array}{l}\text { Aluminium } \\
\text { Tembaga } \\
\text { Perak } \\
\text { Vanadium } \\
\text { Chromium } \\
\text { Samarium } \\
\text { Gadolinium } \\
\text { Cobalt } \\
\text { Tallium }\end{array}$ \\
\hline Ukuran sampel & $\begin{array}{l}\text { Diameter } 25 \mathrm{~mm} \\
\text { Panjang } 96 \mathrm{~mm}\end{array}$ & Bola s.d diameter $2 \mathrm{~mm}$ \\
\hline Berat sampel & Maksimum $70 \mathrm{~g}$ & $0,01-0,05 \mathrm{~g}$ \\
\hline Ukuran kapsul & $\begin{array}{c}\text { Diameter luar } 33 \mathrm{~mm} \\
\text { Panjang } 96 \mathrm{~mm}\end{array}$ & $\begin{array}{c}\text { Diameter luar } 18 \mathrm{~mm} \\
\text { Panjang } 46 \mathrm{~mm}\end{array}$ \\
\hline $\begin{array}{l}\text { Berat sampel dan } \\
\text { kapsul }\end{array}$ & Maksimum $100 \mathrm{~g}$ & Maksimum $10 \mathrm{~g}$ \\
\hline Panas spesifik & $15 \mathrm{~W} / \mathrm{g}$ & $5 \mathrm{~W} / \mathrm{g}$ \\
\hline
\end{tabular}

\section{Aktivasi dan Persamaan Peluruhan}

Dalam AAN, kecepatan cacah A dari peluruhan sinar gamma yang dipancarkan oleh radionuklida pada saat pengukuran tergantung pada kecepatan disintegrasi (D), pada akhir iradiasi, yang proposional dengan jumlah unsur target dalam cuplikan. Rumus dasar dalam AAN untuk aktivasi dan peluruhan radionuklida dengan waktu paruh $\mathrm{t}_{1 / 2}$ adalah sebagai berikut ${ }^{[2]}$ :

$$
\begin{aligned}
& \mathrm{D}=(\mathrm{NWF} / \mathrm{M}) \mathrm{R}\left[1-\exp \left(-\lambda \mathrm{T}_{\mathrm{i}}\right)\right] \\
& \mathrm{A}=\varepsilon \operatorname{TDexp}\left(-\lambda \mathrm{T}_{\mathrm{d}}\right)
\end{aligned}
$$

Dimana :

$$
\begin{aligned}
\mathrm{N}= & \text { bilangan Avogadro, } 6,023 \times 10^{23} \\
& \text { atom/mol } \\
\mathrm{W}= & \text { berat unsur diiradiasi dalam gram } \\
\mathrm{F}= & \text { abundance dari isotop target }
\end{aligned}
$$


$\mathrm{M}=$ berat atom unsur

$\mathrm{R}=$ kecepatan reaksi nuklir per inti isotop target

$\lambda=$ konstanta peluruhan $\left(\ln 2 / \mathrm{t}_{1 / 2}\right)$ radionuklida

$\mathrm{T}=$ branching ratio dari sinar gamma yang teridentifikasi

$\varepsilon \quad=$ efisiensi detektor

$\mathrm{Ti}=$ lama iradiasi

Td = lama peluruhan

Pada reaksi dengan neutron, pembentukan produk tergantung pada besar fluks neutron $^{[3]}$. Semakin besar fluks neutron, maka semakin besar kecepatan aktivasi, yang juga sebanding dengan jumlan inti yang teraktivasi dalam target. Jumlah inti dalam target ini tergantung pada isotopic abundance dari isotop yang diamati. Sedangkan bilangan Avogadro menyatakan jumlah total atom didalam tiap unsur dengan berat atom tertentu.

\section{Akurasi dan Presisi}

Akurasi adalah kesesuaian antara hasil suatu analisis dan nilai benar analit/unsur, karena nilai hasil analisis pada kenyataannya merupakan perkiraan nilai benar dengan memperhitungkan nilai ketidakpastiannya. Pengujian akurasi dapat dilakukan dengan 2 cara, yaitu :

a. Analisis bahan acuan, hasilnya dibandingkan dengan nilai analit sebenarnya. Selisihnya memberikan nilai penyimpangan dari metode.

b. Analisis bahan acuan/uji, hasilnya dibandingkan dengan hasil pengukuran dengan menggunakan metode lain. Selisihnya memberikan nilai penyimpangan metode relatif terhadap metode lain. Hal ini biasanya dilakukan apabila tidak tersedia bahan acuan.

Perbedaan antara nilai target (nilai dalam sertifikat) dengan nilai hasil analisis dinyatakan dengan empat parameter ${ }^{[4]}$ :

1. Bias relatif antara nilai hasil analisis dengan nilai target yang dinyatakan dalam persentase:

$$
\mathrm{BR}=\frac{\text { Nilai }_{\text {}}{ }_{\text {analisis }}-\text { Nilai }_{\text {target }}}{\text { Nilai }_{\text {target }}} \times 100 \%
$$

2. Nilai z-score, dihitung dengan persamaan berikut

$$
\mathrm{Z}_{\text {score }}=\frac{\text { Nilai }_{\text {analisis }}-\text { Nilai }_{\text {target }}}{\sigma}
$$

Standar deviasi $(\sigma)$ merupakan fungsi Horwitz dengan nilai

$\sigma_{\mathrm{H}}=0,02 \times \mathrm{c}^{0,8495}$ dimana $\mathrm{c}$ adalah fraksi konsentrasi 
3. Simpangan baku z

$$
\mathrm{Z}=\frac{\mathrm{Nilai}_{\text {analisis }}-\mathrm{Nilai}_{\text {target }}}{\sqrt{\mathrm{U}^{2}{ }_{\text {analisis }}+\mathrm{U}^{2}{ }_{\text {target }}}}
$$

4. Nilai u-test dihitung berdasarkan rumus berikut

$$
u_{\text {test }}=\frac{\mid \text { Nilai }_{\text {target }}-\text { Nilai }_{\text {analisis }} \mid}{\sqrt{\mathrm{U}^{2}{ }_{\text {target }}+\mathrm{U}^{2}{ }_{\text {analisis }}}}
$$

Nilai u-test terhitung dibandingkan dengan nilai kritikal dalam Tabel 1, untuk menentukan apakah hasil yang dilaporkan berbeda secara signifikan dengan nilai target dengan tingkat probabilitas sebagai berikut ${ }^{[4]}$

Tabel 2. Tabel T-Statistik

\begin{tabular}{cll}
\hline Kondisi & \multicolumn{1}{c}{ Probabilitas } & \multicolumn{1}{c}{ Status } \\
\hline $\mathrm{u}<1,64$ & lebih besar dari 0,1 & $\begin{array}{l}\text { Hasil yang dilaporkan tidak berbeda secara } \\
\text { signifikan dari nilai target }\end{array}$ \\
$1,95>\mathrm{u}>1,64$ & antara 0,1 dan 0,05 & $\begin{array}{l}\text { Hasil yang dilaporkan kemungkinan tidak berbeda } \\
\text { secara signifikan dengan nilai target } \\
\text { Tidak jelas apakah hasil yang dilaporkan berbeda }\end{array}$ \\
$3,58>\mathrm{u}>1,95$ & antara 0,05 dan 0,01 & $\begin{array}{l}\text { secara signifikan dari nilai target } \\
\text { Hasil yang dilaporkan kemungkinan berbeda } \\
\text { secara signifikan dari nilai target }\end{array}$ \\
$\mathrm{u}>3,29$ & antara 0,01 dan 0,001 & $\begin{array}{l}\text { Hasil yang dilaporkan secara signifikan berbeda } \\
\text { dari nilai target. }\end{array}$ \\
\hline
\end{tabular}

\section{Kriteria Penerimaan}

Kriteria penerimaan untuk pengujian tingkat akurasi dan presisi metode digunakan persamaan berikut :

1. Akurasi hasil pengujian baik (lolos) apabila memenuhi persamaan berikut:

$$
\left|\mathrm{Nilai}_{\text {target }}-\mathrm{Nilai}_{\text {analisis }}\right| \leq 1,95 \times \sqrt{\mathrm{U}^{2} \text { target }+\mathrm{U}^{2} \text { analisis }}
$$

2. Presisi (tergantung pada tingkat konsentrasi) hasil pengujian, baik(lolos) apabila :

$$
\sqrt{\left(\frac{\mathrm{U}_{\text {target }}}{\mathrm{Nilai}_{\text {target }}}\right)^{2}+\left(\frac{\mathrm{U}_{\text {analisis }}}{\mathrm{Nilai}_{\text {analisis }}}\right)^{2}} \times 100 \% \leq \sqrt{\left(\frac{\mathrm{U}_{\text {target }}}{\text { Nilai }_{\text {target }}}\right)^{2}+\left(\sigma_{\mathrm{H}}\right)^{2}} \times 100 \%
$$

\section{PELAKSANAAN PENELITIAN}

\section{Preparasi Sampel}

\section{Bahan}

Pada kegiatan ini digunakan beberapa bahan acuan standar NIST 1573a Tomato Leaves, SRM 2702 Inorganic Marine Sediment, SRM 1547 Peach Leaves, SRM 2780 Hard Rock Mine Waste, dan SRM 2711 Montana Soil. 


\section{Cara Kerja}

Sampel ditimbang dalam vial poliethylen bersih dengan berat antara 50-150 mg, sebanyak tujuh kali replikat. Dibuat satu larutan standar tetes campuran dengan komposisi dan konsentrasi yang mendekati dengan nilai yang tertera dalam sertifikat untuk unsur-unsur yang akan diuji. Larutan standar multielemen sebanyak $100 \mu \mathrm{l}$ diteteskan ke dalam vial yang telah dicuci kemudian dibiarkan mengering dengan cara menyimpannya dalam desikator selama 3-4 hari. Kemudian dilakukan pengkapsulan sampel dan standar dengan kapsul iradiasi yang terbuat dari poliethylene, dimana setiap layer dalam kapsul iradiasi diberi larutan standar yang akan digunakan untuk kuantifikasi.

\section{Iradiasi}

Sampel, unsur standar dan blanko diiradiasi secara bersamaan pada posisi dan kondisi iradiasi yang sama. Iradiasi dilakukan dalam fasilitas sistim rabbit RSGGAS selama 5 - 10 menit.untuk unsur dengan waktu paruh medium dan 1 jam untuk unsur dengan waktu paruh panjang. Kemudian didinginkan selama waktu tertentu sebelum dilakukan pencacahan.

\section{Pencacahan}

Pencacahan sampel pasca iradiasi yang telah didinginkan dilakukan dengan detektor resolusi tinggi (HpGe), dengan lama pengukuran sekitar 15-30 menit untuk unsur waktu paruh medium, dan 1-2 jam untuk unsur dengan waktu paruh panjang. Posisi sampel dan unsur standar terhadap detektor adalah sama.

\section{Analisis Data}

Dari hasil pencacahan dilakukan analisis kualitatif dan kuantitatif. Nilai hasil analisis kemudian dibandingkan terhadap nilai sertifikat dari masing-masing bahan, untuk diuji nilai akurasi dan presisinya. Dari hasil pengujian tersebut dapat digunakan untuk mengetahui kemapuan kinerja fasilitas sistem iradiasi yang digunakan.

\section{HASIL DAN PEMBAHASAN}

Hasil pengujian diperoleh pada penelitian ini, ditunjukkan oleh Tabel 3 dan Tabel 4. Dari Tabel 3 dapat diketahui hasil analisis sampel SRM 2702, dimana iradiasi sampel dilakukan pada posisi RS 1, dengan waktu cooling selama 7 hari dan waktu counting 1 jam untuk radionuklida dengan umur panjang. Dapat terdeteksi unsur-unsur waktu paruh panjang diantaranya adalah Sc yang memiliki tingkat akurasi dan presisi bagus, memiliki nilai konsentrasi yang mendekati nilai sebenarnya (tercantum dalam sertifikat dari NIST). Unsur Sc ini terbentuk dari reaksi ${ }^{45} \mathrm{Sc}(\mathrm{n}, \gamma)^{46} \mathrm{Sc}$, memiliki isotop abundance 1,00 dan tampang lintang reaksi neutron $\left(\sigma_{\mathrm{th}}\right) 26,3$ barn $\left(26,310^{-28} \mathrm{~m}^{2}\right)$. Demikian juga dengan unsur $\mathrm{Cr}, \mathrm{Fe}, \mathrm{Co}$, $\mathrm{Pa}, \mathrm{Ba}$ dan $\mathrm{Rb}$ didapat hasil pengujian yang memiliki nilai akurasi dan presisi 
baik. Sedangkan Sb memiliki nilai akurasi bagus tetapi presisi tidak baik, ini karena pada saat pengulangan pengujian dihasilkan nilai yang agak berjauhan /bervariasi.

Pada pengujian dimana aktivasi dilakukan pada fasilitas Rabbit system-2 (RS2) dengan pengulangan sebanyak tujuh kali, menunjukkan bahwa hasil analisis untuk unsur Sc memberikan nilai konsentrasi di dalam kisaran nilai benar dari nilai yang sebenarnya, demikian juga dengan unsur $\mathrm{Cr}, \mathrm{Fe}, \mathrm{Co}, \mathrm{Pa}$, dan $\mathrm{Rb}$ memberikan nilai akurasi dan presisi yang cukup bagus. Sedangkan untuk unsur Ba konsentrasi terukur jauh di bawah nilai sertifikat dan setelah diuji tingkat akurasi dan presisinya tidak bagus. Konsentrasi unsur $\mathrm{Sb}$ terukur di atas nilai sertifikat.

Untuk aktivasi yang dilakukan pada RS3 memberikan hasil pengujian lebih baik dibandingkan RS2. Pada iradiasi dengan fasilitas ini memberikan hasil analisis untuk unsur $\mathrm{Sc}, \mathrm{Cr}, \mathrm{Fe}, \mathrm{Co}, \mathrm{Pa}, \mathrm{Ba}$, dan $\mathrm{Rb}$ dengan tingkat akurasi dan presisi yang baik. Kecuali untuk unsur $\mathrm{Sb}$ memberikan hasil yang cukup akurat, tetapi presisinya jelek.

Sedangkan aktivasi yang dilakukan pada RS4 memberikan hasil analisis unsur-unsur yang tidak akurat dan presisi. Semua unsur yang terdeteksi nilainya jauh di bawah nilai sertifikat, sehingga setelah dilakukan pengujian akurasi, semuanya tidak lolos (ditolak), walaupun pada pengulangan memiliki tingkat presisi yang baik.

Dari keseluruhan kegiatan pengujian untuk validasi metode yang telah dilakukan, bila dilihat hasilnya dapat diketahui bahwa pada analisis sampel jenis yang sama, tetapi dilakukan pada fasilitas RS4 memberikan hasil validasi yang kurang bagus. Fluks neutron di lokasi iradiasi dilakukan, berpengaruh terhadap hasil aktivasi yang didapat. Semakin besar fluks neutron, maka semakin bagus kecepatan aktivasinya dan ini sebanding pula dengan jumlah inti teraktivasi dalam target. Dari hasil pengukuran yang dilakukan terhadap fluks neutron thermal di RS1, RS2, RS3 dan RS4 (Tabel 2) pada saat penelitian ternyata memberikan nilai kisaran luks neutron yang hampir sama sekitar 4,86× $10^{13}-5,45$ $\times 10^{13} \mathrm{~m}^{-2} \mathrm{~s}^{-1}$. Sehingga dapat dipastikan bahwa pada pengujian ini pengaruh posisi iradiasi terhadap hasil analisis tidak signifikan. Waktu iradiasi sampel dibuat sama yaitu masing-masing 1 jam. Sampel juga dicacah pada detektor yang sama, dengan jarak antara sampel dan standar pembanding terhadap permukaan detektor juga dibuat sama. Jadi perbedaan hasil pengujian yang diperoleh bukan disebabkan karena perbedaan posisi/kondisi aktivasi, kemungkinan disebabkan karena faktor lainnya seperti : perbedaan berat sampel yang diaktivasi. Sensitifitas pengujian akan semakin baik dengan adanya kenaikan berat sampel, dan pada pengujian ini berat sampel yang diaktivasi pada RS1, memang paling besar.(lihat Tabel 5) Berat atom, isotopic abundance dan tampang lintang tiap 
unsur target dalam sampel juga berpengaruh terhadap sensitifitas hasil, semakin besar nilainya maka sensitifitas hasil yang diperoleh akan semakin baik.

Pada penelitian ini juga telah dilakukan analisis bahan SRM untuk unsurunsur dengan waktu paruh medium, dimana aktivasi bahan dilakukan pada fasilitas iradiasi RS1 dan RS2. Hasil analisis dan pengujian ditunjukkan oleh Tabel 4. Dari tabel hasil dapat diketahui konsentrasi beberapa unsur yang dapat dianalisis dan hasil perhitungan ketidakpastiannya serta pengujian tingkat akurasi dan presisi hasil analisis dengan dibandingkan terhadap nilai sertifikat.

Pada analisis NIST SRM 2702 Inorganic Marine Sediment dapat dikuantifikasi 5 unsur yaitu $\mathrm{La}, \mathrm{Sb}, \mathrm{As}, \mathrm{Na}$ dan W. Empat buah unsur (La, Sb, As, $\mathrm{Na}$ ) setelah dilakukan pengujian ternyata memiliki nilai akurasi dan presisi bagus, sedangkan unsur $\mathrm{W}$ tidak dapat diuji tingkat akurasi dan presisinya, karena unsur tersebut nilai kuantifikasinya pada sertifikat termasuk daftar unsur yang nilainya belum certified, tetapi memiliki nilai yang merupakan nilai informasi (information mass fraction).

Pada analisis NIST SRM 1547 Peach Leaves dan NIST SRM 1573a Tomato Leaves dapat dikuantifikasi unsur-unsur $\mathrm{Br}$, La, K, As dan tambahan $\mathrm{Sb}$ untuk SRM 1573a. Pada peach leaves unsur K setelah diuji ternyata memiliki nilai presisi yang baik demikian juga dengan akurasinya sehingga hasil pengujian akhir memberikan hasil baik. Sedangkan pada pengujian unsur As, akurasinya baik akan tetapi tingkat presisinya tidak lolos. Pada pengujian tingkat akurasi dan presisi unsur $\mathrm{As}, \mathrm{Sb}$, dan $\mathrm{K}$ dengan tomato leaves, hanya unsur $\mathrm{K}$ yang lolos. Demikian juga pada pengujian menggunakan NIST 2780 Hard Rock Mine Waste dan NIST SRM 2711 Montana Soil, hanya unsur-unsur yang memiliki nilai certified saja yang bisa diuji tingkat akurasi dan presisinya.

Tabel 3. Flux Neutron Thermal Pada Fasilitas Iradiasi Sistem Rabbit ${ }^{[11]}$

\begin{tabular}{llll}
\hline No & Posisi & $\begin{array}{c}\text { Flux neutron } \\
\left(\mathrm{n} \mathrm{cm}^{-2} \mathrm{~s}^{-1}\right)^{*}\end{array}$ & $\begin{array}{l}\text { Flux neutron } \\
\left(\mathrm{n} \mathrm{cm}^{-2} \mathrm{~s}^{-1}\right)^{[5]}\end{array}$ \\
\hline 1. & $\mathrm{RS}-1$ & $4,86 \times 1013$ & $4,19 \times 1013$ \\
2. & $\mathrm{RS}-2$ & $5,10 \times 1013$ & $5,09 \times 1013$ \\
3. & $\mathrm{RS}-3$ & $5,45 \times 1013$ & $5,97 \times 1013$ \\
4. & RS-4 & $5,45 \times 1013$ & $6,46 \times 1013$ \\
\hline
\end{tabular}


Tabel 3. Hasil Analisis SRM 2702 pada Pengujian Sistem Rabbit Reaktor.

\begin{tabular}{|c|c|c|c|c|c|c|c|c|c|c|c|c|}
\hline \multirow[t]{2}{*}{ Posisi } & \multirow[t]{2}{*}{ Unsur } & \multicolumn{2}{|c|}{ Hasil analisis } & \multicolumn{2}{|l|}{ Sertifikat } & \multicolumn{2}{|c|}{ Kriteria akurasi } & \multirow[b]{2}{*}{ Status } & \multicolumn{2}{|l|}{ Kriteria Presisi } & \multirow[b]{2}{*}{ Status } & \multirow{2}{*}{$\begin{array}{l}\text { Status } \\
\text { akhir }\end{array}$} \\
\hline & & $\begin{array}{l}\text { Nilai } \\
(\mathrm{mg} / \mathrm{kg})\end{array}$ & $\mathrm{U}^{*}( \pm)$ & $\begin{array}{l}\text { Nilai } \\
(\mathrm{mg} / \mathrm{kg})\end{array}$ & $\mathrm{U}^{*}( \pm)$ & $\left|N_{t}-N_{a}\right|$ & $1,95 \times \sqrt{U^{2}{ }_{t}+U^{2}{ }_{a}}$ & & $\sqrt{\left(\frac{U_{t}}{N_{t}}\right)^{2} \div\left(\frac{U_{a}}{N_{a}}\right)^{2}} \times 100 \%$ & $\sqrt{\left(\frac{U_{t}}{N_{t}}\right)^{2}+\left(\sigma_{H}\right)^{2}} \times 100 \%$ & & \\
\hline RS1 & $\mathrm{Sc}$ & 24,4 & 1,2 & 25,9 & 1,1 & 1,5 & 3,2 & diterima & 6,6 & 32,0 & diterima & diterima \\
\hline RS1 & $\mathrm{Cr}$ & 345,5 & 20,3 & 352,0 & 22,0 & 6,5 & 58,4 & diterima & 8,6 & 291,4 & diterima & diterima \\
\hline RS1 & $\mathrm{Fe}$ & 77488 & 4142 & 79100 & 0,58 & 1612 & 8076 & diterima & 5,3 & 28976 & diterima & diterima \\
\hline RS1 & Co & 27,0 & 1,7 & 27,8 & 0,58 & 0,8 & 3,4 & diterima & 6,5 & 33,7 & diterima & diterima \\
\hline RS1 & $\mathrm{Sb}$ & 6,4 & 1,8 & 5,6 & 0,24 & 0,8 & 3,5 & diterima & 27,9 & 9,7 & ditolak & ditolak \\
\hline RS1 & $\mathrm{Pa}$ & 18,6 & 1,1 & 20,5 & 0,96 & 1,9 & 2,8 & diterima & 7,3 & 26,5 & diterima & diterima \\
\hline RS1 & $\mathrm{Ba}$ & 333 & 76 & 397 & 3,23 & 64 & 149 & diterima & 22,9 & 322,6 & diterima & diterima \\
\hline RS1 & $\mathrm{Rb}$ & 141,6 & 25,3 & 127,7 & 8,80 & 13,9 & 52,3 & diterima & 19,2 & 123,3 & diterima & diterima \\
\hline RS2 & $\mathrm{Sc}$ & 25,3 & 1,3 & 25,9 & 1,1 & 0,6 & 3,3 & diterima & 6,6 & 32,0 & diterima & diterima \\
\hline RS2 & $\mathrm{Cr}$ & 354,7 & 23,0 & 352,0 & 22,0 & 2,7 & 62,1 & diterima & 9,0 & 291,4 & diterima & diterima \\
\hline RS2 & $\mathrm{Fe}$ & 76955 & 4112 & 79100 & 0,58 & 2145 & 8019 & diterima & 5,3 & 28976 & diterima & diterima \\
\hline RS2 & $\mathrm{Co}$ & 29,8 & 2,1 & 27,8 & 0,58 & 2,0 & 4,3 & diterima & 7,4 & 33,7 & diterima & diterima \\
\hline RS2 & $\mathrm{Sb}$ & 8,8 & 2,4 & 5,6 & 0,24 & 3,2 & 4,8 & diterima & 28,2 & 9,65 & ditolak & ditolak \\
\hline RS2 & $\mathrm{Pa}$ & 21,2 & 1,3 & 20,5 & 0,96 & 0,67 & 3,15 & diterima & 7,72 & 26,45 & diterima & diterima \\
\hline RS2 & $\mathrm{Ba}$ & 230 & 84,5 & 397 & 3,23 & 167 & 165 & ditolak & 36,7 & 322,63 & diterima & ditolak \\
\hline RS2 & $\mathrm{Rb}$ & 193,7 & 42,5 & 127,7 & 8,80 & 66,0 & 84,5 & diterima & 22,9 & 123,3 & diterima & diterima \\
\hline RS3 & $\mathrm{Sc}$ & 24,3 & 1,2 & 25,9 & 1,1 & 1,6 & 3,2 & diterima & 6,7 & 32,0 & diterima & diterima \\
\hline RS3 & $\mathrm{Cr}$ & 312,6 & 16,7 & 352,0 & 22,0 & 39,4 & 53,9 & diterima & 8,2 & 291,4 & diterima & diterima \\
\hline RS3 & $\mathrm{Fe}$ & 77163 & 4417 & 79100 & 0,58 & 1938 & 8612 & diterima & 5,7 & 28976 & diterima & diterima \\
\hline RS3 & Co & 24,8 & 2,0 & 27,8 & 0,58 & 3,0 & 4,1 & diterima & 8,3 & 33,7 & diterima & diterima \\
\hline RS3 & $\mathrm{Sb}$ & 4,4 & 1,2 & 5,6 & 0,24 & 1,2 & 2,5 & diterima & 28,6 & 9,7 & ditolak & ditolak \\
\hline RS3 & $\mathrm{Pa}$ & 20,5 & 1,3 & 20,5 & 0,96 & 0,01 & 3,2 & diterima & 7,9 & 26,5 & diterima & diterima \\
\hline RS3 & $\mathrm{Ba}$ & 442,5 & 116,3 & 397 & 3,23 & 45,5 & 226,8 & diterima & 26,3 & 322,6 & diterima & diterima \\
\hline RS3 & $\mathrm{Rb}$ & 131,2 & 22,6 & 127,7 & 8,80 & 3,5 & 47,3 & diterima & 18,6 & 123,3 & diterima & diterima \\
\hline RS4 & $\mathrm{Sc}$ & 19,1 & 1,0 & 25,9 & 1,1 & 6,8 & 2,9 & ditolak & 6,6 & 32,0 & diterima & ditolak \\
\hline RS4 & $\mathrm{Cr}$ & 231,6 & 13,0 & 352,0 & 22,0 & 120,4 & 49,9 & ditolak & 8,4 & 291,4 & diterima & ditolak \\
\hline RS4 & $\mathrm{Fe}$ & 61866 & 3467 & 79100 & 0,58 & 17234 & 6761 & ditolak & 5,6 & 28976 & diterima & ditolak \\
\hline RS4 & $\mathrm{Co}$ & 22,9 & 1,6 & 27,8 & 0,58 & 4,9 & 3,3 & ditolak & 7,3 & 33,7 & diterima & ditolak \\
\hline RS4 & $\mathrm{Sb}$ & 10,9 & 2,1 & 5,6 & 0,24 & 5,3 & 4,2 & ditolak & 19,9 & 9,65 & ditolak & ditolak \\
\hline RS4 & $\mathrm{Pa}$ & 15,5 & 0,9 & 20,5 & 0,96 & 5,0 & 2,6 & ditolak & 7,4 & 26,45 & diterima & ditolak \\
\hline RS4 & $\mathrm{Ba}$ & 230,8 & 52,3 & 397 & 3,23 & 166,2 & 102,1 & ditolak & 22,7 & 322,63 & diterima & ditolak \\
\hline RS4 & $\mathrm{Rb}$ & 73,0 & 7,6 & 127,7 & 8,80 & 54,7 & 22,7 & ditolak & 12,5 & 123,3 & diterima & ditolak \\
\hline
\end{tabular}

$\mathrm{U}^{*}$ : Uncertainty, ketidak pastian dengan tingkat kepercayaan $95 \%$ dan $\mathrm{k}=2$

$\sigma_{\mathrm{H}}=0,02 \times \mathrm{c}^{0,8495}$ dengan c adalah fraksi konsentrasi 
Tabel 4. Hasil Pengujian Akurasi dan Presisi Metode INAA di Lab AAN-RSG dengan Beberapa NIST-SRM

\begin{tabular}{|c|c|c|c|c|c|c|c|c|c|}
\hline \multirow[t]{2}{*}{ Unsur } & \multirow[t]{2}{*}{ Hasil pengujian } & \multirow[t]{2}{*}{ Nilai sertifikat } & \multicolumn{2}{|c|}{ Kriteria akurasi } & \multicolumn{3}{|c|}{ Kriteria Presisi } & \multirow[b]{2}{*}{ Status } & \multirow[t]{2}{*}{ Status akhir } \\
\hline & & & $\left|N_{t}-N_{a}\right|$ & $1,95 \times \sqrt{U^{2}{ }_{t}+U^{2}{ }_{a}}$ & Status & $\sqrt{\left(\frac{U_{t}}{N_{t}}\right)^{2} \div\left(\frac{U_{a}}{N_{a}}\right)^{2}} \times 100 \%$ & $\sqrt{\left(\frac{U_{t}}{N_{t}}\right)^{2}+\left(\sigma_{H}\right)^{2}} \times 100 \%$ & & \\
\hline \multicolumn{10}{|c|}{ NIST SRM 2702 Inorganic Marine Sediment } \\
\hline $\mathrm{La}$ & $74,88 \pm 2,20$ & $73,5 \pm 4,2$ & 1,38 & 9,25 & diterima & 6,43 & 77,20 & diterima & diterima \\
\hline As & $44,50 \pm 5,32$ & $45,3 \pm 1,8$ & 0,8 & 10,95 & diterima & 12,60 & 51,19 & diterima & diterima \\
\hline $\mathrm{Na}$ & $6486 \pm 549$ & $6810 \pm 200$ & 3,4 & 1138,64 & diterima & 8,95 & 3608,18 & diterima & diterima \\
\hline $\mathrm{W}$ & $7,72 \pm 0,7$ & 6,2 & 1,52 & & & & & & \\
\hline \multicolumn{10}{|c|}{ NIST SRM 1547 Peach Leaves } \\
\hline $\mathrm{Br}$ & $13,2 \pm 1$ & 11 & 2,2 & & & & & & \\
\hline $\mathrm{La}$ & $7,60 \pm 0,6$ & 9 & 1,4 & & & & & & \\
\hline K & $25900 \pm 2329$ & $24300 \pm 300$ & 1600 & 4580 & diterima & 9,07 & 10632 & diterima & diterima \\
\hline As & $0,08 \pm 0,02$ & $0,06 \pm 0,018$ & 0,02 & 0,053 & diterima & 39,05 & 30,0 & ditolak & ditolak \\
\hline \multicolumn{10}{|c|}{ NIST SRM 2780 Hard Rock Mine Waste } \\
\hline $\mathrm{W}$ & $20,70 \pm 1,80$ & 24 & 3,3 & & & & & & \\
\hline $\mathrm{Zr}$ & $183 \pm 16,5$ & 183 & 0 & & & & & & \\
\hline AS & $53,20 \pm 4,20$ & $48,8 \pm 3,3$ & 4,4 & 10,42 & diterima & 9,07 & 10632 & diterima & diterima \\
\hline $\mathrm{Na}$ & $2209 \pm 44,04$ & $2210 \pm 180$ & 1,20 & 361,35 & diterima & 39,05 & 30,0 & ditolak & ditolak \\
\hline $\mathrm{Sb}$ & $172 \pm 11,3$ & 160 & 12 & & & & & & \\
\hline $\mathrm{Au}$ & $0,20 \pm 0,0216$ & 0,18 & 0,02 & & & & & & \\
\hline $\mathrm{La}$ & $33,50 \pm 3,10$ & 38 & 4,5 & & & & & & \\
\hline \multicolumn{10}{|c|}{ NIST SRM 2711 Montana Soil } \\
\hline $\mathrm{K}$ & $25609 \pm 1235$ & $24500 \pm 800$ & 1109 & 2869,37 & diterima & 5,82 & 10706 & diterima & diterima \\
\hline $\mathrm{Ga}$ & $13 \pm 1,0$ & 15 & 2 & & & & & & \\
\hline $\mathrm{Na}$ & $12408 \pm 987$ & $11400 \pm 300$ & 1008 & 2011,59 & diterima & 8,38 & 5589,47 & diterima & diterima \\
\hline As & $108 \pm 9$ & $105 \pm 8$ & 3 & 23,48 & diterima & 11,29 & 104,52 & diterima & diterima \\
\hline $\mathrm{Br}$ & $4,5 \pm 0,4$ & 5 & 0,5 & & & & & & \\
\hline $\mathrm{Sb}$ & $18,9 \pm 1,2$ & $19,4 \pm 1,8$ & 0,5 & 4,22 & diterima & 11,24 & 26,51 & diterima & diterima \\
\hline $\mathrm{La}$ & $40,3 \pm 4,9$ & 40 & 0,3 & & & & & & \\
\hline W & $2,6 \pm 0,3$ & 3 & 0,4 & & & & & & \\
\hline $\mathrm{Zr}$ & $242 \pm 18$ & 230 & 1,2 & & & & & & \\
\hline \multicolumn{10}{|c|}{ NIST SRM 1573a Tomato Leaves } \\
\hline $\mathrm{Sb}$ & $0,070 \pm 0,01$ & $0,063 \pm 0,01$ & 0,007 & 0,0195 & diterima & 14,88 & 9,53 & ditolak & ditolak \\
\hline As & $0,10 \pm 0,01$ & $0,112 \pm 0,01$ & 0,012 & 0,013 & diterima & 6,15 & 3,58 & ditolak & ditolak \\
\hline K & $2825 \pm 875$ & $27000 \pm 500$ & 1258 & 1965,1 & diterima & 3,61 & 11627,16 & diterima & diterima \\
\hline $\mathrm{Br}$ & $1280 \pm 89$ & 1300 & 20 & 8 & & & & & \\
\hline $\mathrm{La}$ & $2,1 \pm 0,5$ & 2,3 & 0,2 & & & & & & \\
\hline
\end{tabular}


Tabel 5. Data Hasil Penimbangan SRM 2702

\begin{tabular}{lll}
\hline Posisi & Kode & Berat (gr) \\
Iradiasi & Cuplikan & \\
\hline RS-1 & 1.1. & 0,07187 \\
& 1.2 & 0,07201 \\
& 1.3 & 0,07034 \\
& 1.4 & 0,07132 \\
& 1.5 & 0,07023 \\
& 1.6 & 0,07234 \\
RS-2 & 1.7 & 0,07543 \\
& 2.1 & 0,06895 \\
& 2.2 & 0,06598 \\
& 2.3 & 0,06456 \\
& 2.4 & 0,06987 \\
& 2.5 & 0,06578 \\
& 2.6 & 0,06347 \\
RS-3 & 2.7 & 0,06583 \\
& 3.1 & 0,06823 \\
& 3.2 & 0,06578 \\
& 3.3 & 0,06681 \\
& 3.4 & 0,06533 \\
& 3.5 & 0,06755 \\
& 3.6 & 0,06781 \\
& 3.7 & 0,06977 \\
& 4.1 & 0,04677 \\
& 4.2 & 0,05644 \\
& 4.3 & 0,05431 \\
& 4.4 & 0,05198 \\
& 4.5 & 0,05341 \\
& 4.6 & 0,05466 \\
& 4.7 & 0,05723 \\
\hline
\end{tabular}

\section{KESIMPULAN}

Dari hasil pengujian dalam rangka mengetahui hubungan antara hasil validasi metode AANI dengan posisi aktivasi di fasilitas iradiasi yang ada di RSG-GAS dapat disimpulkan bahwa, dari lima jenis bahan acuan diperoleh dua belas unsur yang telah lolos kriteria presisi dan akurasi. Adapun pengaruh posisi iradiasi terhadap hasil analisis/pengujian tidak signifikan. Perbedaan hasil yang diperoleh kemungkinan disebabkan oleh adanya perbedaan berat cuplikan, maupun faktor pencacahan, karena dari hasil pengukuran diketahui bahwa fluks neutron pada ke-empat posisi iradiasi tersebut memiliki nilai kisaran yang hampir sama yaitu $10^{13} \mathrm{n} \mathrm{cm}^{-2} \mathrm{~s}^{-1}$.

\section{DAFTAR PUSTAKA}

1. ANONIMOUS, "Safety Analysisi Report", Vol 1, rev.8 MPR G.A Siwabessy, BATAN. 
2. IAEA-TECDOC-564, 1990, "Practical Aspects of Operating a Neutron Activation Analysis Laboratory", a technical document issued by the IAEA, Vienna.

3. SUSAN J. P, 1991, “Activation Spectrometry in Chemical Analysis". Vol.119, John Wiley \& Sons.

4. IAEA, 03 January, 2003, "Summary Report of the Proficiency Test for the IAEA Project RAS/2/010: Quality Assurance and Quality Control of Nuclear Analytical Techniques", Seiberdorf.

5. AMIR H, Juni 2003, "Analisis Parameter f dan $\alpha$ serta Faktor k0 di fasilitas iradiasi Reaktor RSG-GAS”, Jurnal Teknologi Reaktor Nuklir, Tri Dasa Mega, Vol.5, No 2, ISSN 1411-240X.

6. NIST, 2004, "Certificate of Analysis Standard Reference Material 2702 Inorganics in Marine Sediment”, Gaithersburg, MD 20899, Certificate Issue date January 07.

7. NIST, 1994, "Certificate of Analysis Standard Reference Material 1547 Peach Leaves", Gaithersburg, MD 20899, Certificate Issue date Feb 7.

8. NIST, 2003, "Certificate of Analysis Standard Reference Material 2780 Hard Rock Mine Waste", Gaithersburg, MD 20899, Certificate Issue date Jan 31.

9. NIST, 1993, "Certificate of Analysis Standard Reference Material Montana Soil", Gaithersburg, MD 20899, Certificate Issue date August 23.

10. NIST, 1995, "Certificate of Analysis Standard Reference Material 1573a Tomato leaves", Gaithersburg, MD 20899, Certificate Issue date Nov 22.

11. SUWOTO DKK, 2005, "Evaluasi Fluks Neutron Thermal dan Epithermal di Fasilitas Iradiasi Rabbit System”, Prosiding Seminar Hasil Penelitian P2TRR. 
